\title{
On the Cultivation Methods of Entrepreneurial Talents in Higher Vocational Colleges under the Background of "Internet+"
}

\author{
Dao Zhou \\ Hunan International Business Vocational College, Changsha, Hunan 410201, China.
}

Keywords: "Internet+"; higher vocational college; entrepreneurial talent; cultivation methods.

\begin{abstract}
With the reform and change of China's social system, the diversified development of vocation forms imposes unprecedented pressure on the employment of college students, so that the employment mode of college students is gradually changing towards the entrepreneurial mode. Nowadays, the focus of teaching and personnel training in colleges and universities is gradually changing from the perspective of passive practitioners to positive entrepreneurs. The cultivation of college students' entrepreneurial quality and ability is subdivided into perfecting the evaluation criteria of entrepreneurship education, creating entrepreneurial team of teachers, reforming teaching organizational form, building characteristic entrepreneurship education curriculum system, defining the cultivation objectives of entrepreneurial talents, etc. The cultivation of college students' entrepreneurship consciousness is mainly divided into developing entrepreneurship practice, cultivating students' interest in entrepreneurship, establishing incentive mechanism, stimulating students' entrepreneurial motivation, and guiding students to locate entrepreneurial goals, etc.
\end{abstract}

\section{Introduction}

The number of students in China is increasing with the increasing popularity of expanding enrollment in colleges and universities, which leads to increasing competition and pressure of employment. Under such double pressure of fierce competition and increasing employment pressure, college students' entrepreneurship has become an inevitable form of employment. At the same time, college students are required to have more professional knowledge and ability, because of the continuous reform and improvement of social vocation forms, the gradual penetration of Internet technology into people's life and work and the rapid development of social economy. In other words, they must have the consciousness and ability to start a business on the basis of traditional theoretical study. This paper analyzes the methods of cultivating entrepreneurial talents in higher vocational colleges in China under the background of "Internet+", aiming at providing references for future professionals to carry out relevant researches.

\section{Cultivation Methods of Entrepreneurial Talents in Higher Vocational Colleges}

It is the education core of colleges to improve students' self-awareness and initiative of becoming self-employed, so as to cultivate modern innovative and entrepreneurial talents. Centering on this goal, schools should take specific practice of college Students' entrepreneurship and entrepreneurial projects as the main way to infiltrate the entrepreneurship education for college students into all aspects of the comprehensive cultivation [1]. Entrepreneurship education can not only make a reasonable supplement to the disadvantages that undergraduates lack social experience, but also can enhance the professional skills of undergraduates in entrepreneurship through practical operations. Compared with those who have accepted professional entrepreneurship education, college students who have not undergone professional entrepreneurship training are far from enough to recognize and adapt new things. Therefore, based on the actual situation of social development so far in China, the education and cultivation of entrepreneurial talents in colleges and universities should mainly focus two aspects to achieve the pre-set goals: one is the cultivation of college students' awareness of entrepreneurship and the other is cultivation of their entrepreneurial ability. 


\section{Cultivation of Entrepreneurial Consciousness}

Under the traditional examination oriented education mode, colleges and universities mainly focus on the cultivation of applied talents, namely, attaching importance to the training of students' professional knowledge and professional skills. But, facing the ever-changing social form today, the employment pressure that college students suffer is becoming bigger and bigger; if colleges and universities continue educating college students under the cultivation mode of applied talents, the needs of the society for the versatility of talents cannot be satisfied [2].Therefore, the education form that must be applied in China's colleges and universities is to gradually transform from the cultivation of applied talents to the combination of applied talents and entrepreneurial talents. Diversified development directions and the cultivation of thinking consciousness are the most important foundation for entrepreneurial talents. The school and teachers should improve their entrepreneurial thinking and ability from the perspectives of goals, enthusiasm and interest.

\subsection{Guiding Students to Set The Goal of Entrepreneurship}

It is extremely important for an individual in his whole life to have a scientific and rational career planning as well as a clear cognition of the direction and purpose of entrepreneurship. For college students today, the market seemly provides endless opportunities for them in the process of entrepreneurship, which make them feel like dollar bills lying on the sidewalk. However, such illusion makes it impossible for them to have definite entrepreneurial prerequisites like their own investment funds, entrepreneurial capabilities and entrepreneurial experience, which will lead to blind investment and entrepreneurship. They are bound to fail without comprehensive plans, and then it will reduce their enthusiasm to start a business. In view of this problem, college students must focus on their own characteristics and find out the most suitable business project to ensure the accuracy of venture capital, so as to give full play to their abilities. For colleges and universities, they should invite experts and scholars who are authoritative in entrepreneurship to the campus to present professional lectures, so as to further analyze and solve the problems existing in college students' entrepreneurial practice. To solve the problems of college students' lack of entrepreneurial ability and advantages, experts can make actual analysis from perspectives of occupational potential, ability, inclination, hobbies and temperament, so that students can have a clear understanding of themselves [3]. In this way, college students can better locate themselves in the society in the future and set goals in combination with the actual situation.

\subsection{Establishing Incentive Mechanism to Motivate Students' Entrepreneurial Motivation}

For the cultivation mode of college students today, the combination of school and enterprise is the most profitable way for students, the school and the enterprises. The combination of interests of the three can make a benign development cycle. In other words, that the school provides students with the opportunity to practice in enterprises can not only improve the economic benefits of enterprises, but also lays a solid foundation for students to improve their entrepreneurial ability. In this way, the relationship between the enterprises and the school will be more intimate and the school will also receive better reputation because of the good achievements of students. In view of the above, the school and enterprises should set up a fund for student entrepreneurship, helping students with entrepreneurial consciousness and students with entrepreneurial skills in capital and technology. The school should set up a scholarship system and gives a certain number of funds to those who succeed in entrepreneurship as encouragement, which will further enhance their enthusiasm for entrepreneurship and stimulate enthusiasm of other students for entrepreneurship, gradually forming a positive atmosphere for campus entrepreneurship. In the meantime, the school should establish a university-sponsored community and encourage students to actively join. It is necessary to hire government officials and business professionals as part-time teachers to give students regular professional lectures and training. In the lectures, they can elaborate on the difficulties they encountered when starting their own businesses, the lessons learned from their failures, the conditions for their success and other experiences. These experiences will bring the necessary enlightenment for college students to start a business, and increase their ideas, motivation and courage [4]. 


\subsection{Carrying out Entrepreneurial Practice and Cultivate Students' Interest in Entrepreneurship}

The school's emphasis on college students' entrepreneurship is also reflected in hiring professional mentoring teachers and offering professional career guidance courses, because it can cultivate their entrepreneurial ideas, entrepreneurial skills, entrepreneurial ways and entrepreneurship awareness [5]. At the same time, the school and enterprises should jointly create a venue for students' entrepreneurship. On the one hand, the incorporation of large numbers of trainees can help enterprises solve some problems such as saving labor force, relative shortage of labor force and enterprise cost-saving, and so on. On the other hand, it also provides a good opportunity for students to enhance their entrepreneurial practice ability, so that students can get skill of practical operation that cannot be acquired in the school classroom. This approach can not only enables the limited resources of school and enterprises to be optimized in the allocation process, but also enables students to have a positive interest in entrepreneurship in the actual practice in enterprises.

\section{Cultivation of Entrepreneurial Qualities and Abilities}

Entrepreneurial talents should be equipped with comprehensive and all-sided qualities and abilities, including competitive thinking and team thinking. This requires that they not only should have good professional ability, innovation ability and management ability, but should also have outstanding operational ability and practical ability. Therefore, as an institution with strong professional nature, the school should focus on the cultivation of students' entrepreneurial quality and entrepreneurial ability in education and teaching. The school should cultivate students' entrepreneurial quality and entrepreneurial ability in the various specific links, such as the teaching design, practical operation and practical teaching. It is necessary to promote the students' competitive thinking and team thinking, so that their individuality can develop and be promoted freely in the cooperative research and study. At the same time, school should build a workable and rigorous evaluation system and a highly professional faculty for entrepreneurship education, which will play an important role in the cultivation of entrepreneurial talents.

\subsection{Making Clear the Cultivation Goal of Entrepreneurial Talents}

For the cultivation of talents in colleges and universities, the specific direction is the most important. Only by cultivating talents according to the specific needs of the society can colleges and universities ensure that students have strong adaptability and development ability in the future [6]. Nowadays, colleges and universities in China must gradually change the cultivation goal from training traditional technical talents to developing comprehensive technical talents with innovative thinking and entrepreneurial ability for the economic development in the Internet + era.

\subsection{Constructing the Characteristic Curriculum System for Entrepreneurship Education}

After a lot of practical research and investigation, it can be seen that there is a big gap between the college students' entrepreneurial level and the actual needs of the society, and however, some of approaches can be used to make up for the gap. The school can develop a scientific personnel training plan, and then reasonably adjust curriculums of various majors, integrate and consolidate existing basic compulsory courses, elective courses and professional practice courses, promoting the establishment of theoretical courses and practical courses related to the cultivation of entrepreneurial ability. It is feasible to organically combine characteristic entrepreneurial courses into existing professional compulsory courses, such as establishing some fundamental theoretical courses like Entrepreneurial Theory, Introduction to Entrepreneurial Fundamentals, Case Study of Entrepreneurship and International Marketing. The school can take Entrepreneurial Theory as an introductory textbook of entrepreneurship to introduce some basic knowledge to students, including the concept of entrepreneurship, basic knowledge of this specialty, entrepreneurial procedures, etc. The successful phenomena of entrepreneurship listed in the Introduction of Entrepreneurship Fundamentals can be used as cases to introduce the entrepreneurial literacy and entrepreneurial ability that entrepreneurs should have. Case Study of Entrepreneurship is based on the Introduction of Entrepreneurial Fundamentals. The two courses can compare the actual successful and failed cases to 
analyze the factors that lead to the failure of entrepreneurship, and students can draw lessons for their entrepreneurship in the future [7]. International Marketing is to help students have an essential understanding of current international market and educate them to grasp business opportunities accurately, which will help them gain a firm foothold in the fierce market competitions by taking the advantage of diversified marketing measures and methods.

\subsection{Reforming the Organizational Form of Teaching}

In the actual education and teaching, the school should rationally increase the proportion of the practical courses and reduce the proportion of the theoretical courses reasonably. It is also important to abandon the way of instilling knowledge in the traditional examination-oriented education mode and apply the new quality-oriented education mode to develop students' knowledge and innovative ability. In today's environment where Internet technology is widely used, the cultivation of independent entrepreneurship should be organically combined with teaching. The school can take advantage of high-tech technology to simulate the actual entrepreneurial environment, so that students can have a deeper and clearer understanding of relevant professional knowledge in the process of on-site operation, which will further enhance their entrepreneurial capabilities. For example, the virtual business platform and international trade simulation training platform of the school can be used to enable students to experience a series of business operations, such as business decision-making, selecting projects, building teams, business management, promoting products, and so on [8]. At the same time, the school needs to attach greater importance to the cooperating with enterprises and carry out the practice of new type of entrepreneurship, so that students can practice and study in enterprises. If they can have a detailed understanding of the way of operation and development of enterprises and obtain experience of solving various problems, they can accumulate rich experience and lay a solid foundation for the smooth development of their entrepreneurship in the future.

\subsection{Building an Entrepreneurial Teacher Team}

The improvement of the teaching staff is a very important factor influencing the cultivation of students' entrepreneurial quality and ability. Therefore, only improving the construction of teacher staff in China's colleges and universities can guarantee the cultivation level of entrepreneurial talents. However, at present, there are only a small number of professional teachers for entrepreneurship training in colleges and universities, and moreover, they seriously lack professional and practical experience [9]. In this regard, we should learn from the successful experience of foreign countries and then build and develop the teaching staff, with the aim to innovate the training conditions of entrepreneurial talents. Entrepreneurial experts can also be hired to apply professional training on teachers. Meanwhile, the school can make an agreement with enterprises to allow teachers to have experiential learning regularly in enterprises, so as to strengthen teachers' keen scent of market opportunities. Teachers can also apply what they have learned in the teaching of college students, so that the professional level of both teachers and students can be improved.

\subsection{Perfecting the Evaluation Standard of Entrepreneurship Education}

The purpose of education is to cultivate talents for the society -- not only to cultivate talents, but also to cultivate social talents. Therefore, the effect of education should not be evaluated solely based on the achievements of the students themselves, but also according to the social benefits produced by them. On the basis of evaluating students' entrepreneurial quality, the school should bring their contribution to the society into the evaluation content to realize the diversification of the evaluation contents. It is necessary to evaluate students' knowledge mastery and operation ability, so as to achieve a multiple evaluation method which combines with process evaluation and summative assessment. The school should also adopt a unified multiple evaluation system and operable evaluation standards for entrepreneurial education, and promptly draw feedback from the whole society to revise and improve the education system, so as to promote the rapid development of entrepreneurship education [10]. 


\section{Conclusion}

In summary, from the detailed analysis of cultivation methods of entrepreneurial talents in China's higher vocational colleges under the background of "Internet+", it can be seen that, combined with the analysis of the specific situation of social development, the main methods of higher vocational education to cultivate entrepreneurial technical talents include two aspects: the cultivation of entrepreneurial quality and ability, and the cultivation of entrepreneurship awareness. This is also what the state has explicitly put forward in the guideline on promoting entrepreneurship as a starting point of employment: it is needed to attach importance to the content design, overall level of teaching staff and the advanced level of teaching equipment in universities and vocational colleges, and vigorously carry out the practice and cultivation of college students' entrepreneurship. Only in this way can college students transform theory into knowledge and then transform into production power and contribute to the economic development of our country.

Author: Zhou Dao, female (1982.8 -), Han nationality, master of economics and associate professor of Hunan University; research direction: international economy and trade, vocational education.

\section{Acknowledgments}

Funded project:This paper is one of the phased achievements of 2016 education and teaching reform project of vocational colleges in Hunan Province "Research on Entrepreneurship Education in Higher Vocational Colleges under the Background of Internet+” (No.: ZJGB2016132).

\section{References}

[1]. An Guang. Exploration of Innovation and Entrepreneurship Education in Higher Vocational Colleges under the Background of "Internet+" [J]. Vocational Education Forum, 2016 (36): 34-37.

[2]. Sun Congzhong. Exploration on Cultivating Transnational E-commerce Talents in Higher Vocational Colleges under the Background of "Internet+" -- A Case Study of Applied English Major in Ningbo City College of Vocational Technology [J]. Journal of Jiangxi Vocational and Technical College of Electricity, 2015, 29 (4): 21-25, 48.

[3]. Zhang Youchun, Xu Tao, Wang Yong, et al. On the Cultivation of Innovative and Entrepreneurial Talents in the IOT Major of Higher Vocational Schools from the Perspective of "Internet+" -- a case study of Anhui Business Vocational College [J]. Journal of Henan Institute of Science and Technology (SOCIAL SCIENCE EDITION), 2016, 36 (4): 82-85.

[4]. Hou Xiuli, Wu Songfei, Wang Songlin et al. Exploration of Innovation and Entrepreneurship Education in Higher Vocational Colleges under the Background of "Internet+" [J]. Computer Knowledge and Technology, 2017, 13 (18): 98-100.

[5]. Hu Jianda, Tong Xueyang. Research on the Cultivation of Transnational Entrepreneurs in Higher Vocational Education under the Background of "Internet +" [J]. Vocational Education Research, 2016 (5): 77-81.

[6]. Feng Yukun, Xiang Cheng. Study on the Construction Mode of Cultivation System of E-business Innovation and Entrepreneurship Talents in Higher Vocational Colleges under the Form of "Internet +" [J]. Electronic Commerce, 2017 (1): 64-66.

[7]. Yu Yi. Research on the Innovation of Entrepreneurship Education in Higher Vocational Colleges under the Background of "Internet+" [J]. Agriculture Network Information, 2016 (4): 152-154. 
[8]. Han Guowei. A Study of Talent Cultivation Strategies of Entrepreneurial Cross-border E-commerce in the Internet Era [J]. Journal of Hubei Adult Education Institute, 2016,22 (6): 28-31,36.

[9]. Huang Hanling. Higher Vocational entrepreneurship Education in the Context of "Internet+" [J]. Education and Vocation, 2017 (7): 75-78.

[10]. Kan Yahan, Hong Ming, Zhu Ranran, et al. Research on the Training of Innovative Talents in Suzhou Higher Vocational Education under Supply-side Reform -- Taking the development of Suzhou College of Information Technology as an Study Case [J]. Communication of Vocational Education, 2016 (29) 33-37. 